УДК 339.138:656.073

\title{
ПУБЛІЧНІ ЗАКУПІВЛІ ПІДПРИЕМСТВ ЗАЛІЗНИЧНОГО ТРАНСПОРТУ УКРАЇНИ В УМОВАХ РЕФОРМУВАННЯ
}

\author{
Слагін Ю.В., к.е.н., доцент, \\ Кориикова Г.В., махістр (УкрДУЗТ)
}

В статті досліджено сучасні проблеми забезпечення матеріальними ресурсами, ïx ефективного використання в процесі реформування залізничного транспорту. Підкреслено, щя зміна підходів до організації постачання в контексті Закону України «Про публічні закупівлі» вимагає створення інтегрованих матеріальних та інформаційних систем, стратегічне і тактичне узгодження, планування $і$ контроль за створенням та використанням запасів матеріально - технічних ресурсів. Сформульовані пропозииії на підставі практичних результатів проведення відкритих торгів, переговорної прочедури закупівлі, в умовах реформування залізничного транспорту, є надзвичайно актуальними $і$ потребують поглибленого вивчення.

Ключові слова: забезпечення матеріальними ресурсами, Закон Украӥни «Про публічні закупівлі», залізничний транспорт, реформування.

\section{ПУБЛИЧНЫЕ ЗАКУПКИ ПРЕДПРИЯТИЙ ЖЕЛЕЗНОДОРОЖНОГО ТРАНСПОРТА УКРАИНЫ В УСЛОВИЯХ РЕФОРМИРОВАНИЯ}

\author{
Елагин Ю.В., к.э.н., доцент, \\ Кориикова А.В., магистр (УкрГУЖТ)
}

В статье исследованы современные проблемы обеспечения материальными ресурсами, их эффективное использование в условиях реформирования железнодорожного транспорта. Подчеркнуто, что изменение подходов к организачии снабжения, с контексте применения Закона Украины «О публичных закупках», требует создания комплексных интегрированных : материальных и информационных систем, стратегическое и тактическое согласование, планирование и контроль за созданием и использованием запасов материально - технических ресурсов. Сформулированные предложения на основании практических результатов проведения открытых торгов, переговорной процедуры, в условиях реформирования железнодорожного транспорта, являются чрезвычайно актуальными и требуют углубленного изучения.

Ключевые слова: обеспечение материальными ресурсами, Закон Украины «О публичных закупках», железнодорожный транспорт, реформирование.

(C) Єлагін Ю.В., Коршикова Г.В.
Вісник економіки транспорту і промисловості № 59, 2017 


\title{
PUBLIC PROCUREMENT OF UKRAINIAN RAILWAY ENTERPRISES IN THE CONDITIONS OF REFORM
}

\author{
Elagin Yu.V., Candidate of economics sciences, associate Professor \\ Korshikova A.V., post-graduate student (USURT)
}

In this work, modern problems of providing material resources and their effective use in the conditions of railway transport reform was investigated.

It was emphasized that the change of approaches to the organization of supply, with the context of the application of the Law of Ukraine "About public procurement," requires the creation of integrated systems: material, both strategic and tactical coordination, planning and control of creation and use of inventories financially - technical resources. Proposals based on the practical results open tendering, negotiating procurement procedure in the conditions of railway transport reform is extremely important and require deeper study.

Keywords: providing with material resources, the Law of Ukraine "About public procurement", a rail transport, reforming.

Постановка проблеми. Введення в дію Закону України «Про публічні закупівлі» 321 квітня 2016 року та використання його при проведенні закупівель матеріально - технічних ресурсів ПАТ «Укрзалізниця» створило нові умови функціонування залізничного транспорту в цілому. Досягнення мети ефективного, економічного, результативного та прозорого використання коштів держави може бути здійснено про створенні нових принципів здійснення закупівель та використання вже існуючих запасів.

Виконання вимог Закону щодо прозорості, відкритості, конкурентності, зменшення корупційних ризиків не повинно створювати штучний дефіцит матеріально - технічних ресурсів, неритмічне постачання та перешкоджати виконанню основної функції залізничного транспорту: здійсненню перевезення пасажирів і вантажів.

Аналіз останніх досліджень i публікацій. Виділення невирішених частин загальної проблеми. Вивченню проблем та пошуку шляхів забезпечення сталого забезпечення матеріально технічними ресурсами підприємства, проблемам практичного використання Закону України «Про публічні закупівлі» присвячені вітчизняних вчених та практиків: В.Л. Диканя, О.В. Гуртяка, О.О. Підмогильного, О.М. Полякової, В. Цвігуна, О. Шатковського, С. Яременко $[2,3,5,6,8,10]$. Проте специфіка проведення публічних закупівель, як новий спосіб здійснення постачання матеріально - технічних ресурсів, для безперебійного функціонування залізничного транспорту не отримала значного висвітлення.

Сформульовані пропозиції на підставі практичних результатів проведення відкритих торгів, переговорної процедури закупівлі, в умовах реформування залізничного транспорту, є надзвичайно актуальними i в контексті використання Закону України «Про публічні закупівлі» потребують поглибленого вивчення.

Метою статті $\epsilon$ дослідження проблем закупівель матеріальних ресурсів в системі Prozorro та визначення оптимальних процесів постачання i створення запасів для безперебійного функціонування залізничного транспорту.

Виклад основного матеріалу. Аналіз функціонування реформованих

Вісник економіки транспорту і промисловості № 59, 2017 
залізниць різних країн свідчить: практично у всіх країнах залізничний транспорт відіграє соціально важливу роль не тільки у секторі пасажирських перевезень, а і у вантажних, які забезпечують обмін товарами і експлуатаційні витрати, яких входять до собівартості продукції практично всіх галузей економіки.

Сама по собі зміна форми власності не тільки не $\epsilon$ гарантією досягнення поставлених цілей реформування, a i навпаки може призвести до втрати частки майна, доходів і прибутків. При визначенні шляхів і заходів реформування необхідно змінювати засоби не тільки у частині форми власності, а обов'язковє i удосконалення експлуатаційної роботи [4]. Жодне виробництво не може обійтися без залучення ресурсів із зовнішнього середовища. Від організації постачання, своєчасності поставок матеріальних ресурсів на виробництво в необхідних асортименті, кількості та відповідної якості значною мірою залежать рівномірний i ритмічний випуск готової продукції, іiі якість і як результат - рівень прибутку та рентабельності підприємства.

В країнах $\mathrm{CC}$ виділяються такі підходи до функціонування закупівлі:

- економія ( економія витрачених коштів держави);

- результативність (отримання прийнятного результату за вкладені кошти);

- ефективність (забезпечення потреби закупівлі саме того обсягу, який необхідний).

Публічні закупівлі розглядають не тільки як інструмент зменшення державних витрат, а й як відповідний механізм для зменшення корупції в країні. Далі в таблиці звернемо увагу на переваги та недоліки публічних електронних закупівель через систему Prozorro:

Табличя 1

Переваги та недоліки публічних електронних закупівель у системі Prozorro

\begin{tabular}{|l|l|}
\hline Переваги закупівель & Недоліки закупівель \\
\hline Економія до $20 \%$ & $\begin{array}{l}\text { Цінові маніпуляції та низький рівень виявлення } \\
\text { підставних фірм }\end{array}$ \\
\hline Професіоналізація закупівель & $\begin{array}{l}\text { Потенційне зниження шансів на успіх для малих та } \\
\text { середніх підприємств }\end{array}$ \\
\hline Зменшення корупції & $\begin{array}{l}\text { Електронне подання всієї документації суперечить } \\
\text { законодавству про захист персональних даних і } \\
\text { через їх доступність уможливлює використання } \\
\text { інформації в злочинних цілях }\end{array}$ \\
\hline Ефективність закупівель & $\begin{array}{l}\text { Неповне охоплення ринку потенційних учасників } \\
\text { тендерних торгів }\end{array}$ \\
\hline $\begin{array}{l}\text { Отримання прийнятного } \\
\text { результату }\end{array}$ & $\begin{array}{l}\text { Можливість відсіву учасників (в т.ч. зі злочинною } \\
\text { метою) в процесі постаукційній кваліфікації }\end{array}$ \\
\hline
\end{tabular}

Використання системи електронних закупівель надає переваги, але створює низку проблем для постачання матеріальних ресурсів.

Проаналізуємо переваги та недоліки здійснених закупівель в системі Прозорро в
2016 та 2017 роках на прикладі Філії «Вінницятрансприлад».

Переваги: (безперечні)

1. Економія. Якщо в 2016 році зниження вартості закупівель склало $10 \%$, то станом на 01.05.2017 року - 12,5\%.

Вісник економіки транспорту і промисловості № 59, 2017 
2. Професіоналізація закупівель. Приведення у відповідність предмету закупівель Єдиному закупівельному словнику, використання кінцевої кількості критеріїв для визначення переможця, можливість кількаразової перевірки (як системою торгівельного майданчика, так і спеціалістами тендерного комітету), зменшуються часові витрати на проведення тендеру завдяки автоматизації усіх дій по його оголошенню (так при проведені повторних відкритих торгів немає необхідності повторно розробляти комплект документів, відбувається копіювання за зразком та заміна термінів аукціону).

3. Зменшення

корупції. Використання онлайн системи при здійсненні публічних закупівель підвищує відкритість та прозорість цієї процедури. Результат тендерів відкритий на сайті Прозорро для всіх бажаючих. Оскарження результату проведеного тендеру проводиться в електронному вигляді, що зменшує паперову роботу та можливості зловживань.

Переваги або недоліки ( за відмінних обставин):

1. Ефективність закупівель забезпечення потреби закупівлі в необхідному обсязі відбувається не завжди. Так в 2016 році не відбулося 8 закупівель, 3 яких по 5 позиціях - матеріали та запасні частини, для виготовлення основної продукції, а в 2017 році це 5 закупівель та 3 закупівлі відповідно. Також слід зазначити, що основні торги на закупівлю запасних частин та обладнання ще не проводилися, а саме по цим позиціям виникають проблемні питання. Особливо це стосується запасних частин та приладдя до устаткування, яке було збудовано за радянських часів. Закупівлі матеріалів 3 груп: метал, інструмент, підшипники, дизпаливо та бензин, мастильні матеріали, паперова канцелярія, папір офісний, господарчі товари, проводяться більш успішно.

2. Отримання прийнятного результату. Чітке визначення предмету закупівлі, можливість проведення онлайн обговорення закупівлі 3 майбутніми постачальниками, виконання процедур вхідного контролю продукції відділом технічного контролю підвищує можливість отримання якісної продукції за результатами тендеру. Але використання виразу «або еквівалент», ставить під питання існування розроблених та затверджених норм на виробництво продукції підприємства, в яких вказано конкретний матеріал, його кількість. Також еквівалент не завжди можна використати в контексті придбання запасних частин.

Недоліки:

1. Неповне охоплення ринку потенційних учасників тендерних торгів (через недостатній моніторинг самими суб'єктами постачальниками). Неодноразово траплялися випадки, коли можливі постачальники звертались та пропонували придбання матеріалів після проведених тендерів, не маючи відомостей про те, що будуть проводитися аукціони по закупівлі.

2. Потенційне зниження шансів для малих та середніх підприємств. Так фізичні особи підприємці не мають достатньої підготовки для проведення тендерів. При проведенні закупівель вони часто, виграючи по ціні, не надавали комплект документів та їх пропозиції відхилялися.

3. Цінові маніпуляції та низький рівень виявлення підставних фірм. Був єдиний випадок, коли в фірми переможця було виявлено відсутність кінцевого бенефіциара.

Не зважаючи на реальні результати економії коштів, з'явився ряд проблем, що потребують вирішення та постійного контролю:

1. Закупівля матеріалів, які $\epsilon$ в нормах на виробництво основної продукції,

Вісник економіки транспорту і промисловості № 59, 2017 
але їх річна норма в грошовому еквіваленті не перевищує 50 тис. грн. (Приклад: батист, фарба для друку, поролон, спирт, мийний засіб);

2. Закупівля матеріалів, які використовуються для виготовлення пристосувань та оснащення (з особливих видів сталі, або в розмірах, які не можуть продаватися як оптові або мілкооптові партії);

3. Закупівля запасних частин для ремонту та обслуговування металообробних верстатів та іншого обладнання, виготовленого за радянських часів наприклад: отримані запасні частини - це законсервовані з тривалого зберігання;

4. Підвищення ціни до $10 \%$ за укладеним договором ставить під питання що головніше: закупити весь матеріал, створити запаси, не збільшувати вартість, але не дотримуватися встановленого нормативу запасів, або дотримуватися нормативу запасів, але мати високу вірогідність того, що в продовж терміну дії договору, або буде підвищуватися ціна, або постачальник відмовиться і філія отримає «простій» в зв'язку 3 відсутністю матеріалів.

Окрім недоліків на шляху придбання матеріалів слід зазначити ще одну проблему - запаси. Запаси визнаються активом, якщо існує вірогідність того, що підприємство отримає в майбутньому економічні вигоди, пов'язані 3 їх використанням. Створення запасів може відбуватися декількома шляхами закупівель: відкриті торги, переговорна процедура, конкурентний діалог. Але використання цих методів не дасть упевненості в здійсненні закупівлі згідно встановленого регламенту проведення торгів. Терміни закупівлі можуть бути значно змінені: при відміні торгів за умови подання менше двох тендерних пропозицій, оскарження торгів або рішення про закупівлю, відмові переможця при значному підвищенні цін на ринку від постачання товару до моменту укладання договору, ненадання переможцем довідок по ст. 16 та 17 Закону України «Про публічні закупівлі» та інше. Тобто ніхто не дасть гарантію, що закупівля відбудеться.

В сучасних умовах господарювання, враховуючи використання Закону «Про публічні закупівлі», необхідно ретельно стежити за створенням запасів та ефективно використовувати вже існуючі. Згідно наказів та Методики розрахунку нормативу запасів матеріально - технічних ресурсів на залізничному транспорті [11]. виділяються запаси: зайві - запаси ТМЦ, які не використовуються у виробничому процесі більше одного року; неходові запаси ТМЦ, які не використовуються у виробничому процесі шести місяців; морально застарілі - запаси ТМЦ, які не придатні для експлуатації за технічними параметрами. Існуючий аналіз на теперішній час не повністю охоплює всі види запасів ТМЦ. Приклад: для виготовлення пристовувань або оснащення придбано бронза та мідь. Виготовлення оснащення здійснюється впродовж року за потребою. Якщо збільшується випуск продукції - збільшується кількість оснащення, i як наслідок кількість використаної міді та бронзи. Але через півроку цей матеріал вже неходовий. Гірший стан із запасними частинами до устаткування з терміном придбання більше 15 років.

В цілому можна сказати, що впровадження системи публічних електронних закупівель, призведе до наступних позитивних наслідків [8]:

- забезпечить прозору та вільну конкуренцію у сфері публічних закупівель; - підвищить ефективність використання грошових коштів замовниками;

- усуне прояви зайвої бюрократії;

- дасть змогу використовувати спеціальні інструменти та персонал для

Вісник економіки транспорту і промисловості № 59, 2017 
закупівель, уникати помилок під час проведення торгів;

- посилить публічний контроль закупівель.

Висновки i перспективи

подальших досліджень. Для сталої роботи підприємств залізничного транспорту пропонується вжити наступні кроки:

1. На теперішній час контроль за закупівлями підприємства здійснюється Департаментом матеріально - технічного забезпечення. Проте при використання системи «Моніторинг» відсутня можливість отримувати інформацію про закупівлі та сумлінних постачальників на аналогічні товари інших залізничних підприємств. Пропонується для членів тендерного комітету зробити можливість отримання даної інформації згідно 3 кодами Єдиного закупівельного словника та кодами Фобос.

2. Створити Методику визначення планової вартості закупівлі для правильного визначення економії коштів.

3. Створити базу даних для аналізу та обліку обслуговування та ремонту обладнання. 3 часу створення ПАТ «УЗ» кожний основний засіб отримав свій інвентарний номер в автоматизованій системі бухгалтерського обліку «ФОБОС». Аналіз вартості закупівель та постачальників дозволить мати цілісну картину по групах устаткування та можливість в подальшому вибрати найраціональнішій спосіб утримання їх в робочому стані. Якщо систематично не будуть здійснюватися закупівлі самих запасних частин та обладнання, то виникне необхідність скорочення персоналу ремонтних бригад, та переведення обслуговування обладнання на аутсорсінг за договорами.

4. Переглянути, або розробити нові Нормативи запасу для сталої роботи підприємства, які виготовляють серійну продукцію, i які повинні своєчасно отримувати матеріали та комплектуючі для уникнення простоїв. А саме слід виділити: матеріали, які необхідні для виготовлення основної продукції або послуг згідно встановлених норм. Згідно Закону на рік закуповується планова річна норма, і якщо не закінчився термін придатності, ці матеріали не можуть входити до категорії неходові; матеріали для обслуговування або ремонту устаткування маркуються і не вносяться до груп зайві або неходові при збереженні їх якості та придатності; матеріали, які не втрачають своїх якісних характеристик більший час, ніж піврічний проміжок часу, не обраховувати як зайві або неходові.

Отже для удосконалення роботи 3 матеріально - технічного постачання необхідна корпоративна логістична стратегія по кожній 3 функціональних вертикалей, яка дозволить не зупинити виробництво в зв'язку 3 тривалою закупівлею необхідного матеріалу та ефективно використовувати систему публічних закупівель.

\section{ПЕРЕЛІК ВИКОРИСТАНИХ ДЖЕРЕЛ}

1 Закон України Про публічні закупівлі. Закон України № 922-VIIII від 25 грудня 2015 року. [ Електронний ресурс]. Режим доступу: http://zakon2.rada.gov.ua/laws/show/922-19.

2 Гуртяк О.В. Основні проблеми під час участі у тендерних закупівлях діагностичного обладнання для служб електропостачання [ Електронний ресурс]. - Режим доступу: http://ukrrailways.com/statti/2339-stvorennyamerezhi-vuzkokolijnikh-zaliznits-u-zakarpatti2.html.

3. Дикань В.Л. Особливості реформування Національної транспортної системи /Дикань В. Л., Єлагіна О. М., // Вісник економіки транспорту i промисловості. - 2002. - № 1. - С. 17-21.

4 . Слагін Ю.В. Основні умови ефективного реформування залізничного

Вісник економіки транспорту і промисловості № 59, 2017 
транспорту./ Ю.В. Слагін, В.С. Лебедська // Вісник економіки транспорту і промисловості. - 2012 - № 37 - С. 115-117

5.Слагін Ю. В. Перспективи розвитку транспортної логістики на підприємствах залізничного транспорту / Ю. В. Слагін, Г. В. Обруч // Вісник економіки транспорту і промисловості. 2014. - № 48. - С. 121-123.

6 Закупки нуждаются в новых подходах - интервью с главой закупочного филиала "Укрзализныци" [ Електронний peсурс]. - Режим доступу: http://cfts.org.ua/articles/zakupki_nuzhdayutsy a_v_novykh_podkhodakh_intervyu_s_glavo y_zakupochnogo_filiala_ukrzaliznytsi_1173

7 Закуповувати розумно, або як Укрзалізниця реформує тендерні процедури [ Електронний ресурс]. Режим доступу: https://smarttender.biz /news- view?id=141.

8 Підмогильний О.О. Проблемні питання шляхів впровадження електронних торгів як механізму забезпечення ефективності системи державних закупівель України [ Електронний ресурс]. - Режим доступу: http://www.dy.nayka.com.ua/?op=1\&z=270.

9 «Укрзализныця» отменила тендеры на закупку еще 1,5 тысяч вагонов [ Електронний pecypc]. - Режим доступу:https://ru.slovoidilo.ua/2017/02/27 /novost/jekonomika/ukrzaliznycya-otmenilatendery-na-zakupku-eshhe-15-tysyachivagonov

10 Шатковський О. Коментарі до законодавства про публічні закупівлі [ Електронний ресурс] / О.Шатковський, С.Яременко. - Режим доступу: http://eupublicprocurement.org.ua/ wpcontent/uploads/2017/01/PPLCommentary_2017_UKR.pdf.

11 Методика розрахунку нормативу запасів матеріально - технічних ресурсів на залізничному транспорті: виробничо практичне видання. Донецьк: видавництво "УкрНТЕК", 2002 р.

\title{
УДК 656.08
}

\section{ТЕОРЕТИЧНІ ЗАСАДИ ПІДВИЩЕННЯ РІВНЯ ТЕХНОЛОГІЧНОЇ БЕЗПЕКИ ЗАЛІЗНИЧНОГО ТРАНСПОРТУ}

\author{
Корінь М.В., к.е.н., доцент, \\ Кривда В.М., махістр (УкрДУЗТ)
}

В статті визначено, щзо критичний рівень спраџьованості технікотехнологічної бази залізничного транспорту негативно впливає на якість послуг українських залізниць $і$ відповідно, створює загрозу для подальшого ефективного та безпечного функціонуванню галузі, підриваючи тим самим рівень ї̈ технологічної безпеки. Вивчення підходів до визначення змісту категорії «технологічна безпека» дозволило представити авторське бачення технологічної безпеки залізничного транспорту з точки зору стану його техніко-технологічної бази, щуо відповідає стандартам транспортного законодавства, та за якого створюється можливість для надання комплексних транспортно-логістичних послуг (дотримання термінів та висока швидкість доставки, оптимальний марщрут та гнучкість відправлень,

(C) Корінь М.B., Кривда B.M.
Вісник економіки транспорту і промисловості № 59, 2017 